\title{
Pathogenic roles of alterations in vitamin D and vitamin D receptor in gastric tumorigenesis
}

\author{
Chao Du ${ }^{1,2}$, Shiming Yang ${ }^{1}$, Xiaoyan Zhao ${ }^{1}$ and Hui Dong ${ }^{1,3}$ \\ ${ }^{1}$ Department of Gastroenterology, Xinqiao Hospital, Third Military Medical University, Chongqing, China \\ 2 Department of Gastroenterology and Hepatology, Chengdu Military General Hospital, Chengdu, Sichuan Province, China \\ ${ }^{3}$ Division of Gastroenterology, Department of Medicine, School of Medicine, University of California, San Diego, California, \\ USA \\ Correspondence to: Xiaoyan Zhao, email: zhaoxx@medmail.com.cn \\ Hui Dong, email: h2dong@ucsd.edu \\ Keywords: vitamin D, vitamin D receptor, gastric cancer, tumorigenesis \\ Received: December 10,2016 Accepted: January 20, $2017 \quad$ Published: February 11, 2017 \\ Copyright: Du et al. This is an open-access article distributed under the terms of the Creative Commons Attribution License (CC-BY), which \\ permits unrestricted use, distribution, and reproduction in any medium, provided the original author and source are credited.
}

\section{ABSTRACT}

\begin{abstract}
Gastric cancer is currently the second leading cause of cancer-related death worldwide, especially in Japan, Korea and China, and the 5-year survival rate of gastric cancer is less than $\mathbf{3 0} \%$. Thus, it is important to shed more lights on novel agents to prevent gastric cancer or to improve survival rate of the patients. Vitamin D not only maintains calcium and bone homeostasis, but also mostly inhibits tumor genesis, invasion, and metastasis through activation of vitamin D receptor. Although epidemiological results are not consistent, accumulating evidence from gastric cancer cells, animal models, and clinical trials suggest that vitamin $D$ deficiency may increase the risk and mortality of gastric cancer, but vitamin $D$ supplement might be a safe and economical way to prevent or treat gastric cancer. Here, we reviewed the current studies on vitamin $D$ and its receptor and focused on the pathogenic roles of their alterations in gastric tumorigenesis.
\end{abstract}

\section{INTRODUCTION}

Gastric cancer is the fourth most common cancer and the second leading cause of cancer-related death in the world. An estimated 1 million new cases of gastric cancer occurred and over 0.7 million patients died worldwide in 2012 only [1]. Currently, gastric cancer is difficult to prevent and cure because of the poor understanding of its pathogenesis and difficulty in its early diagnosis. Even worse, the future burden of gastric cancer is expected to rise with the increase in worldwide population and aging process [2]. Therefore, gastric cancer is regarded as a major public health problem in the world. Multiple therapies (surgery, chemotherapy, radiotherapy, immunotherapy, etc.) are applied to gastric cancer although surgical resection is considered the primary choice for the early stage $[3,4]$. Despite of much progress in the pathogenesis, diagnosis and treatment of gastric cancer, its 5-year survival rate is still less than 30\% [5]. Therefore, it is urgent to investigate gastric tumorigenesis and to elucidate the underlying molecular mechanisms so that the best ways for preventment and treatment could be developed to decrease the current high morbidity and mortality of gastric cancer.

It is well known that vitamin D plays an important role in maintaining calcium and bone homeostasis and participates in a variety of biological processes in our body as well [6]. It has long been thought low vitamin D status and inadequate calcium intake are important risk factors for various types of human cancer. As early as in 1980, the ultraviolet-B (UVB)-vitamin D-cancer hypothesis was first proposed by Garland [7] who demonstrated that vitamin $\mathrm{D}$ is a protective factor against the development of colon cancer. Since then, numerous studies have shown that vitamin D could inhibit the tumorigenesis and prevent tumor progression of breast, colon, skin, pancreas and many other cancers [8-12]. The potential anti-tumor mechanisms of vitamin D may be relevant to its specific receptor, vitamin D receptor (VDR) [13]. VDR is a member of the steroid hormone receptor superfamily of ligand-activated transcription factors [14]. An interaction of vitamin D and VDR can induce a cascade of gene 
regulation and cell signaling to play important roles in their anti-tumor mechanisms, such as suppression of proliferation, stimulation of apoptosis and autophagy, inhibition of angiogenesis, regulation of immune system and so on $[15,16]$. Although several reviews on vitamin D and VDR in some types of human cancer were published, there is no a systematic review on their roles in gastric cancer in the literatures so far. Therefore, in this review, we try to assess the association between vitamin D/VDR and gastric cancer, to explore their multiple anti-tumor mechanisms, and to analyze the safety and validity of vitamin D in the clinical therapy for gastric cancer.

\section{VITAMIN D: SOURCES, METABOLISM AND RECEPTOR}

\section{Vitamin D sources}

Vitamin D is not really a vitamin but a prohormone of the steroid hormone calcitriol, which was first discovered and named by McCollum in 1922 [17]. Although at least ten kinds of vitamin D have been found, the most important forms of vitamin D relevant to human health are vitamin $\mathrm{D}_{2}$ (ergocalciferol) and vitamin $\mathrm{D}_{3}$ (cholecalciferol). However, vitamin $\mathrm{D}_{2}$ and $\mathrm{D}_{3}$ are shortage in our normal dietary [18]. Abundant vitamin $\mathrm{D}$ is synthesized in the skin when exposed to sunlight [19]. In brief, the UVB (290-315nm) transforms 7-dehydrocholesterol into previtamin $\mathrm{D}_{3}$ in the skin, and then previtamin $\mathrm{D}_{3}$ is further converted into vitamin $\mathrm{D}$ by thermal isomerization $[20,21]$. In addition, food supplement, such as normal dietary (the least source of vitamin D), fortified food (egg, milk, salmon, etc.) and concentrated natural food (e.g. cod liver oil), is another subordinate source of vitamin D [22].

\section{Vitamin D metabolism}

Since $1 \alpha, 25$-dihydroxyvitamin $\mathrm{D}\left(1 \alpha, 25(\mathrm{OH})_{2} \mathrm{D}_{3}\right.$, calcitriol) nor vitamin $\mathrm{D}$ is the most active metabolite in our body, vitamin D needs two important cytochrome P450-mediated hydroxylation steps in the metabolism. Firstly, vitamin D obtained from both dietary and skin is converted to 25 -hydroxyvitamin $\mathrm{D}_{3}\left(25(\mathrm{OH}) \mathrm{D}_{3}\right)$ by the hepatic 25-hydroxylases (CYP27A1) after transporting to liver via the vitamin D binding protein. Secondly, 25(OH) $\mathrm{D}_{3}$ is hydroxylated again in the kidney by the enzyme 25-hydroxyvitamin D-1 $\alpha$-hydroxylase (CYP27B1) to yield calcitriol (Figure 1). Of course, vitamin D metabolism is alternatively proceeded in other organs and/or cells and is regulated by parathyroid hormone, fibroblast growth factor 23, and calcitriol itself [23-26].

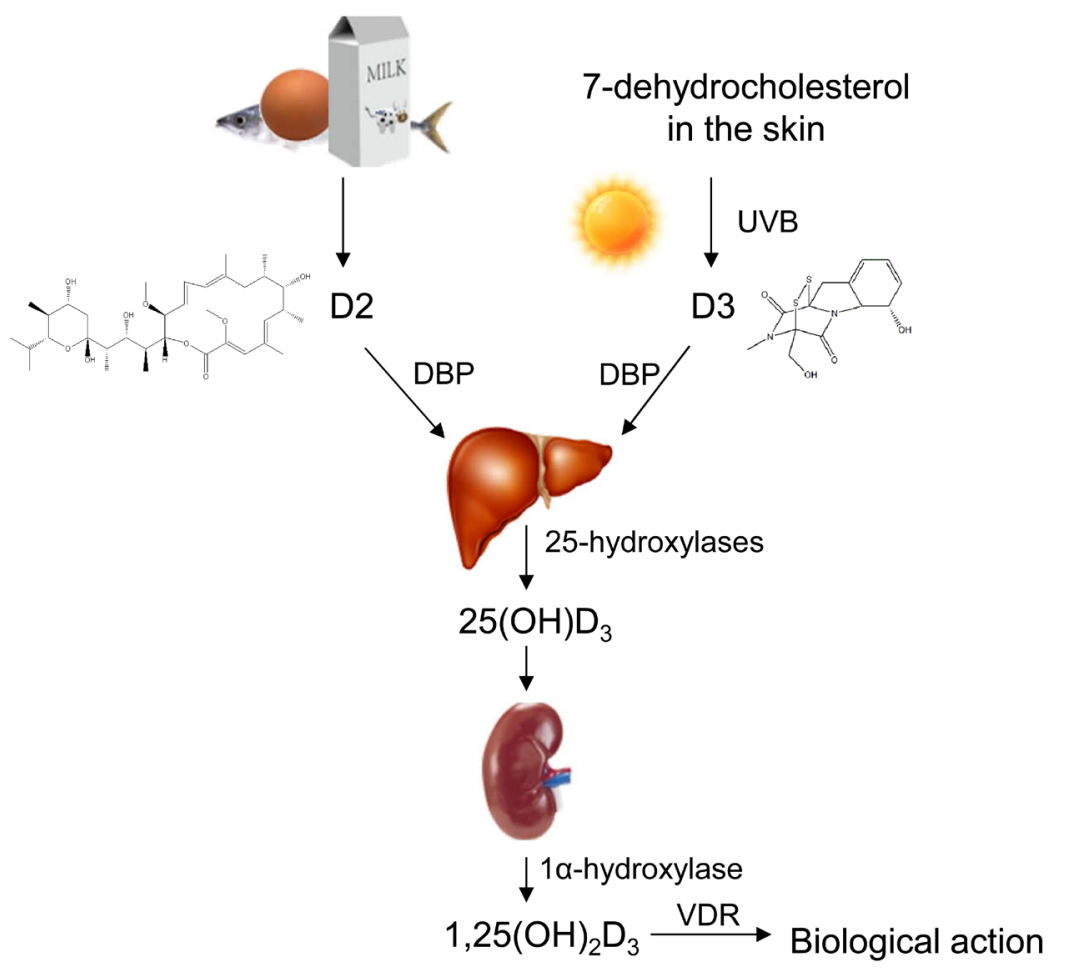

Figure 1: Transforming pathways of vitamin D in human body. Vitamin D can be obtained from foods and synthesized through convertion of 7-dehydrocholesterol by UVB in the skin. The absorbed vitamin D transports into liver by binding to vitamin D binding protein $(\mathrm{DBP})$, then vitamin $\mathrm{D}$ is hydrolysed into form 25 -hydroxyvitamin $\mathrm{D}_{3}\left(25(\mathrm{OH}) \mathrm{D}_{3}\right)$ by 25 -hydroxylase in the liver. Again, $25(\mathrm{OH})$ $\mathrm{D}_{3}$ is hydrolysed into form $1 \alpha, 25$-dihydroxyvitamin $\mathrm{D}_{3}\left(1 \alpha, 25(\mathrm{OH})_{2} \mathrm{D}_{3}\right)$ in the kidney. 
Table 1: Study on correlation of sun exposure and gastric cancer

\begin{tabular}{|c|c|c|c|c|c|}
\hline Study design & $\begin{array}{l}\text { Study period } \\
\text { /Participants }\end{array}$ & Vitamin D index & Outcome & Summary of findings & $\begin{array}{c}\text { References } \\
\text { (year, country) }\end{array}$ \\
\hline Ecologic study & 1970-1994 & $\begin{array}{l}\text { TOMS DNA- } \\
\text { weighted UVB }\end{array}$ & $\begin{array}{l}\text { Mortality of } \\
\text { premature } \\
\text { gastric cancer }\end{array}$ & $\begin{array}{l}\text { Inverse correlation } \\
P<0.001\end{array}$ & $\begin{array}{l}\text { Grant et al. } \\
(2002, \mathrm{US})\end{array}$ \\
\hline Ecologic study & 1961-1990 & $\begin{array}{l}\text { Average annual } \\
\text { hours of solar } \\
\text { radiation }\end{array}$ & $\begin{array}{l}\text { Mortality of } \\
\text { gastric cancer }\end{array}$ & $\begin{array}{l}\text { Inverse correlation } \\
P<0.001\end{array}$ & $\begin{array}{l}\text { Mizoue } \\
\text { (2004, Japan ) }\end{array}$ \\
\hline Ecologic study & 1993-2002 & $\begin{array}{c}\text { Latitude and } \\
\text { Annual erythemally } \\
\text { weighted UVB }\end{array}$ & $\begin{array}{l}\text { Mortality and } \\
\text { incidence of } \\
\text { gastric cancer }\end{array}$ & $\begin{array}{l}\text { Inverse correlation } \\
P<0.001\end{array}$ & $\begin{array}{l}\text { Boscoe et al. } \\
(2006, \mathrm{US})\end{array}$ \\
\hline Ecologic study & 1990-1994 & $\begin{array}{l}\text { Latitude and } \\
\text { dietary supply } \\
\text { factors }\end{array}$ & $\begin{array}{l}\text { Mortality and } \\
\text { incidence of } \\
\text { gastric cancer }\end{array}$ & $\begin{array}{l}\text { Inverse correlation } \\
P<0.05\end{array}$ & $\begin{array}{l}\text { Grant et al. } \\
(2006, \text { western } \\
\text { European) }\end{array}$ \\
\hline Ecologic study & $1970-1994$ & $\begin{array}{l}\text { TOMS DNA- } \\
\text { weighted UVB }\end{array}$ & $\begin{array}{l}\text { Mortality of } \\
\text { gastric cancer }\end{array}$ & $\begin{array}{l}\text { Inverse correlation } \\
P<0.001\end{array}$ & $\begin{array}{l}\text { Grant et al. } \\
(2006, \mathrm{US})\end{array}$ \\
\hline Ecologic study & 1978-1992 & $\begin{array}{l}\text { Latitude, skin } \\
\text { cancer and } \\
\text { melanoma }\end{array}$ & $\begin{array}{l}\text { Mortality of } \\
\text { gastric cancer }\end{array}$ & $\begin{array}{l}\text { Inverse correlation } \\
p<0.01\end{array}$ & $\begin{array}{l}\text { Grant et al. } \\
\text { (2007, Spain) }\end{array}$ \\
\hline Case-control & $\begin{array}{l}416,134 \text { cases } \\
3,776,501 \text { controls }\end{array}$ & $\begin{array}{l}\text { Skin cancer and } \\
\text { sunexposure }\end{array}$ & $\begin{array}{l}\text { Incidence of } \\
\text { gastric cancer }\end{array}$ & $\begin{array}{l}\text { Inverse correlation } \\
\text { SIR: } 0.65 \\
\text { 95\%CI:0.45-0.91 }\end{array}$ & $\begin{array}{l}\text { Tuohimaa et al. } \\
\text { (2007,Five } \\
\text { Continents) }\end{array}$ \\
\hline Ecologic study & 1950-1994 & $\begin{array}{l}\text { TOMS DNA- } \\
\text { weighted UVB }\end{array}$ & $\begin{array}{l}\text { Mortality of } \\
\text { gastric cancer }\end{array}$ & $\begin{array}{l}\text { Inverse correlation } \\
p<0.001\end{array}$ & $\begin{array}{l}\text { Grant et al. } \\
(2010, \text { US })\end{array}$ \\
\hline Ecologic study & 1998-2002 & $\begin{array}{l}\text { UVB from NASA } \\
\text { database and GIS } \\
\text { methods }\end{array}$ & $\begin{array}{l}\text { Mortality of } \\
\text { gastric cancer }\end{array}$ & $\begin{array}{l}\text { Inverse correlation } \\
p<0.001\end{array}$ & $\begin{array}{l}\text { Chen et al. } \\
\text { (2010, China) }\end{array}$ \\
\hline $\begin{array}{l}\text { Nested case- } \\
\text { control }\end{array}$ & $\begin{array}{l}115,016 \text { cases } \\
987,893 \text { controls }\end{array}$ & Skin cancer & $\begin{array}{l}\text { Incidence of } \\
\text { gastric cancer }\end{array}$ & $\begin{array}{l}\text { No correlation } \\
\text { OR: } 1.00 \\
\text { 95\%CI:0.85-1.17 }\end{array}$ & $\begin{array}{l}\text { Lindelof et al. } \\
\text { (2012, Swedish) }\end{array}$ \\
\hline Ecologic study & 2000-2002 & $\begin{array}{c}\text { UVB intensity from } \\
\text { NASA database } \\
\text { and spatial Kriging } \\
\text { method }\end{array}$ & $\begin{array}{l}\text { Mortality of } \\
\text { gastric cancer }\end{array}$ & $\begin{array}{l}\text { Inverse correlation } \\
\text { HR:0.89 } \\
95 \% \mathrm{CI}: 0.83-0.95\end{array}$ & $\begin{array}{l}\text { Chen et al. } \\
\text { (2013,China) }\end{array}$ \\
\hline
\end{tabular}

\section{Vitamin D receptor}

As mentioned above, the biological function of calcitriol is primarily mediated by vitamin $\mathrm{D}$ receptor, which is composed of 427 amino acid residues and belongs to the superfamily of steroid/thyroid hormone receptor [13]. VDR regulates biological function of calcitriol by two mechanisms, one involves transcriptional regulation of nuclear VDR, and the other involves nongenomic signal transduction pathways of membrane VDR [27]. The first one is the most studied anti-tumor mechanism of vitamin D. When activated by calcitriol, the phosphorylated nuclear VDR forms homodimers or heterodimers VDR-
RXR with one of the retinoid X receptors (RXR), then the calcitriol-VDR-RXR complex translocates into nucleus and attaches to the vitamin $\mathrm{D}$ response elements (VDREs) in the promoters of target genes, causing the recruitment of co-activators or co-repressors to regulate gene expression in target cells $[28,29]$. In addition to the genomic responses mediated by nuclear VDR, membrane VDR mediates rapid responses pathways within 1-2 min to 15-45 min, including intestinal absorption of $\mathrm{Ca}^{2+}$ (transcaltachia) [30], secretion of insulin by pancreatic $\beta$-cells [31], opening of voltage-gated $\mathrm{Ca}^{2+}$ and $\mathrm{Cl}^{-}$ channels in osteoblasts and sertoli cells [32, 33], and migration of endothelial cells [34]. 
Table 2: Studies on vitamin D intake and serum vitamin D status in the patients with gastric cancer

\begin{tabular}{|c|c|c|c|c|c|c|}
\hline Study design & Participants & $\begin{array}{l}\text { Exposure } \\
\text { to }\end{array}$ & $\begin{array}{l}\text { Methods of } \\
\text { measurement }\end{array}$ & Outcome & Summary of findings & $\begin{array}{l}\text { References } \\
\text { (year, } \\
\text { country) }\end{array}$ \\
\hline $\begin{array}{l}\text { Case-control } \\
(7 y)\end{array}$ & $\begin{array}{l}723 \text { cases } \\
2,024 \text { controls }\end{array}$ & $\begin{array}{l}\text { Vitamin D } \\
\text { intake }\end{array}$ & Diet history & $\begin{array}{l}\text { Risk of gastric } \\
\text { cancer }\end{array}$ & $\begin{array}{l}\text { Positive correlation } \\
\text { OR:1.35 } \\
\text { 95\%CI: } 1.00-1.83\end{array}$ & $\begin{array}{l}\text { Vecchia et al. } \\
\text { (1994,Italy) }\end{array}$ \\
\hline $\begin{array}{l}\text { Case-control } \\
(10 \mathrm{y})\end{array}$ & $\begin{array}{l}230 \text { cases } \\
547 \text { controls }\end{array}$ & $\begin{array}{l}\text { Vitamin D } \\
\text { intake }\end{array}$ & $\begin{array}{l}\text { Food frequency } \\
\text { questionnaire }\end{array}$ & $\begin{array}{l}\text { Risk of gastric } \\
\text { cancer }\end{array}$ & $\begin{array}{l}\text { No significant correlation } \\
\text { OR: } 1.33 \\
95 \% \mathrm{CI}: 0.80-2.21\end{array}$ & $\begin{array}{l}\text { Pelucchi et } \\
\text { al. } \\
(2009, \text { Italy })\end{array}$ \\
\hline $\begin{array}{l}\text { Prospective } \\
\text { cohort(24y) }\end{array}$ & 1,105 people & $\begin{array}{l}\text { Serum } \\
25(\mathrm{OH}) \mathrm{D}\end{array}$ & ELISA & $\begin{array}{l}\text { Mortality of upper } \\
\text { gastrointestinal } \\
\text { cancers }\end{array}$ & $\begin{array}{l}\text { No correlation } \\
\text { HR:0.97 } \\
\text { 95\%CI:0.88-1.06 }\end{array}$ & $\begin{array}{l}\text { Lin et al. } \\
(2012, \text { China })\end{array}$ \\
\hline $\begin{array}{l}\text { Prospective } \\
\text { cohort( } 5.25 y)\end{array}$ & 2084 people & $\begin{array}{l}\text { Serum } \\
25(\mathrm{OH}) \mathrm{D}\end{array}$ & ELISA & $\begin{array}{l}\text { Risk of gastric } \\
\text { cancer }\end{array}$ & $\begin{array}{l}\text { No significant correlation } \\
\text { HR: } 1.77 \\
95 \% \mathrm{CI}: 1.16-2.70\end{array}$ & $\begin{array}{l}\text { Chen et al. } \\
\text { (2007, China) }\end{array}$ \\
\hline $\begin{array}{l}\text { Pooling } \\
\text { project }\end{array}$ & $\begin{array}{l}1,065 \text { cases } \\
1,066 \text { controls }\end{array}$ & $\begin{array}{l}\text { Serum } \\
25(\mathrm{OH}) \mathrm{D}\end{array}$ & ELISA & $\begin{array}{l}\text { Risk of gastric } \\
\text { cancer }\end{array}$ & $\begin{array}{l}\text { Inverse correlation } \\
\mathrm{OR}=0.65(>100 \mathrm{nmol} / \mathrm{L}) \\
95 \% \mathrm{CI}: 0.26-1.62\end{array}$ & $\begin{array}{l}\text { Abnet et al. } \\
\text { (2010,US, } \\
\text { Finland } \\
\text { and China })\end{array}$ \\
\hline $\begin{array}{l}\text { Prospective } \\
\text { cohort(14y) }\end{array}$ & 51,529 men & $\begin{array}{l}\text { Predicted } \\
25(\mathrm{OH}) \mathrm{D}\end{array}$ & $\begin{array}{l}\text { Model predicting } \\
25(\mathrm{OH}) \mathrm{D}\end{array}$ & $\begin{array}{l}\text { Risk of gastric } \\
\text { cancer }\end{array}$ & $\begin{array}{l}\text { Inverse correlation } \\
\mathrm{RR}=0.58 \\
95 \% \mathrm{CI}=0.26-1.33\end{array}$ & $\begin{array}{l}\text { Giovannucci } \\
\text { et al. } \\
(2006, \mathrm{US})\end{array}$ \\
\hline $\begin{array}{l}\text { Retrospective } \\
\text { case-control }\end{array}$ & $\begin{array}{l}49 \text { cases } \\
49 \text { controls }\end{array}$ & $\begin{array}{l}\text { Serum } \\
25(\mathrm{OH}) \mathrm{D}\end{array}$ & ELISA & $\begin{array}{l}\text { Risk of gastric } \\
\text { adenocarcinoma } \\
\text { with } \\
\text { VD deficiency } \\
\end{array}$ & $\begin{array}{l}\text { Positive correlation } \\
\text { OR=3.8 } \\
\text { 95\%CI: } 1.42-10.18\end{array}$ & $\begin{array}{l}\text { Vyas et al. } \\
(2016, \mathrm{US})\end{array}$ \\
\hline Case-control & $\begin{array}{l}68 \text { cases } \\
20 \text { controls }\end{array}$ & $\begin{array}{l}\text { Serum } \\
25(\mathrm{OH}) \mathrm{D}\end{array}$ & ELISA & $\begin{array}{l}\text { Level in gastric } \\
\text { cancer }\end{array}$ & $\begin{array}{l}\text { Increased in gastric cancer } \\
\mathrm{P}=0.036\end{array}$ & $\begin{array}{l}\text { Fidan et al. } \\
(2010, \\
\text { Turkey) }\end{array}$ \\
\hline $\begin{array}{l}\text { Observational } \\
\text { study }\end{array}$ & 197cases & $\begin{array}{l}\text { Serum } \\
25(\mathrm{OH}) \mathrm{D}\end{array}$ & ELISA & $\begin{array}{l}\text { An independent } \\
\text { prognostic factor } \\
\text { of gastric cancer }\end{array}$ & $\begin{array}{l}\text { Inverse correlation } \\
\mathrm{P}=0.019\end{array}$ & $\begin{array}{l}\text { Ren et al. } \\
\text { (2012,china) }\end{array}$ \\
\hline $\begin{array}{l}\text { Prospective } \\
\text { cohort }\end{array}$ & $\begin{array}{l}\text { 43,468White } \\
\text { men } \\
481 \text { Black men }\end{array}$ & $\begin{array}{l}\text { Vitamin D } \\
\text { Intake }\end{array}$ & $\begin{array}{l}\text { Dietary } \\
\text { questionnaire }\end{array}$ & $\begin{array}{lr}\text { Gastric } & \text { cancer } \\
\text { mortality } & \text { and } \\
\text { incidence } & \\
\text { with } & \\
\text { hypovitaminosis D }\end{array}$ & $\begin{array}{l}\text { Increased incidence } \\
\mathrm{RR}=1.5795 \% \mathrm{CI}=1.16-2.11 \\
\text { Increased mortality } \\
\mathrm{RR}=2.2795 \% \mathrm{CI}=1.57-3.28\end{array}$ & $\begin{array}{l}\text { Giovannucci } \\
\text { et al. } \\
\text { (2006,US) }\end{array}$ \\
\hline
\end{tabular}

\section{VITAMIN D/VDR AND GASTRIC CANCER: EPIDEMIOLOGICAL DATA}

\section{Ultraviolet B (UVB) and vitamin D in gastric cancer}

Abundant vitamin $\mathrm{D}$ is synthesized in the skin by UVB, which is commonly regarded as the major vitamin D . Since Frank Garland proposed the UVBvitamin D-cancer hypothesis in 1980 [7], more and more epidemiology studies support that UVB related vitamin $\mathrm{D}$ deficiency is an important risk factor of cancer incidence and mortality in recent years [35-38]. In the stomach, almost all epidemiological data support a strong inverse association between sunlight exposure and cancer incidence and/or mortality rates [34-44] (Table 1).

Ecological studies in predominantly European populations reported higher cancer survival in areas of higher solar UVB irradiation [39], indicating that high vitamin D status can improve gastric cancer survival. Chen [40] also found the 5-year survival proportions for gastric cancer were inversely associated with ambient UVB in the developing countries. In particular, Boscoe [41] extended the analysis of this relationship to include cancer incidence as well as mortality. After studying over three million cancer cases between 1998-2002 in the United States and three million cancer deaths with daily satellite-measured solar UVB levels between 1993-2002, they found an inverse relationship between solar UVB exposure and cancer incidence and mortality for 10 types 
of cancer, including gastric cancer. Following this initial finding, the protection role of UVB in gastric cancer was continually reported worldwide [42-44]. The people with deficiency of synthesis vitamin D in the skin are also in the high risk and/or mortality of gastric cancer [40-43]. For example, the premature with inadequate doses of solar UVB radiation showed increased gastric cancer mortality in the U.S. [45], the Blacks with low vitamin D levels were found to have higher risk of cancer incidence and mortality especially in digestive system [46]. To further assess whether patients with skin cancer have an altered risk of developing other cancers, a study found that the patients with skin cancer really have a high risk of developing other cancers, and the standardized incidence ratio of gastric cancer in sunny countries was significant lower than in less sunny countries (SIR(S)/ SIR(L) 0.61, $95 \%$ CI $0.38-0.9)$. Moreover, the apparently protective effect of sun exposure against second primary cancer was more pronounced after non-melanoma skin cancers than melanoma [47]. This result was also reported in an ecologic study of cancer mortality rates in Spain [48]. However, another case control study from Sweden [49] showed divergent result, the cases with the diagnosis of basal cell carcinoma in skin had an increased risk of getting another form of cancer, and had no correlation with gastric cancer (OR 1.00, 95\% CI 0.85-1.17). One limitation of this study is the exposure factor bias, whereby the study completely neglects the factor of sun exposure to patients, which may lead to this contradiction. More convincingly, Grant [50] found that solar UVB and vitamin D can reduce the risk of gastric cancer using Hill's criteria for causality. But most of these epidemiological results are from ecologic studies, further investigations to directly measure vitamin D status in vivo are needed.

\section{Vitamin D intake and serum vitamin $D$ in the patients with gastric cancer}

Although the protective role of vitamin $\mathrm{D}$ from solar UVB on gastric cancer is obvious, the relationship between vitamin D intake and serum vitamin D in the patients with gastric cancer is inconsistent. There are about ten cohort studies in all (Table 2). These studies measured serum concentrations of $25(\mathrm{OH}) \mathrm{D}_{3}$ as serum vitamin $\mathrm{D}$ status, and assessed dietary vitamin $\mathrm{D}$ intake by a diet history questionnaire $[51,52]$, or food frequency questionnaire $[53,54]$.

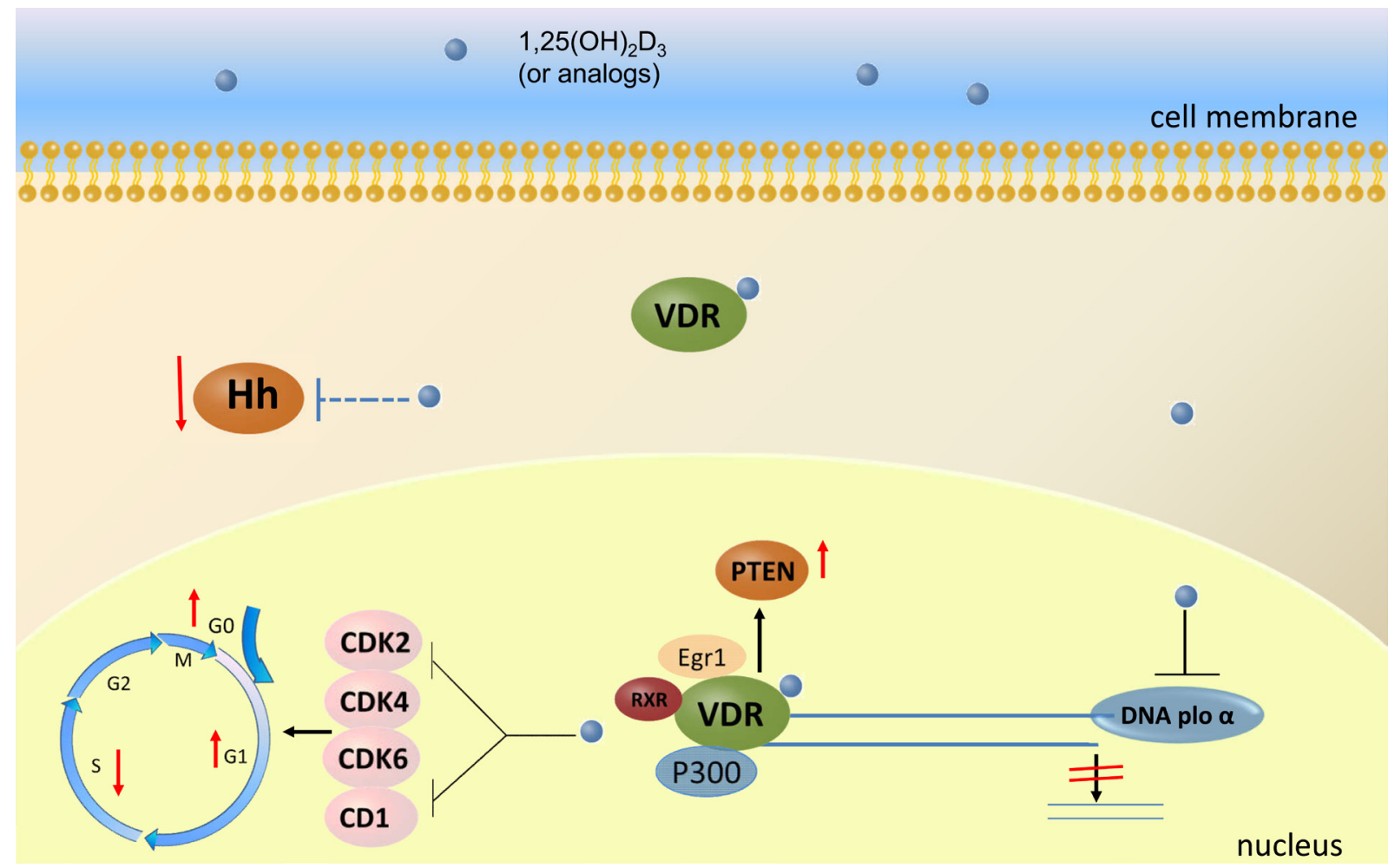

Figure 2: The anti-cancer mechanisms mediated by vitamin $D$ and its analogues through VDR activation in gastric cancer cells. Four cellular signaling pathways are likely involved in the anti-cancer mechanisms of vitamin D: 1) it inhibits mammalian DNA polymerase $\alpha$ to halt NUGC-3 human gastric cancer cells at the G1 phase in the cell cycle, 2) it blocks cell cycle of gastric cancer cells by decreasing the expression of cyclin-dependent kinase, CDK2, CDK4, CDK6 and Cyclin D1, 3) together with VDR, Egr-1 and p300 it induces gastric cancer cell apoptosis through PTEN upregulation, and 4) it acts as an antagonist of hedgehog signaling to suppress viability of gastric cancer cells. CDK: cyclin dependent kinase; PTEN: phosphatase and tensin homolog deleted on chromosome 10; Egr-1: early growth response gene 1; Hh: hedgehog. 
The latest cohort study from China [55]investigated whether baseline serum $25(\mathrm{OH}) \mathrm{D}_{3}$ concentrations were associated with all-cause mortality and cause-specific mortality rates over 24 years of follow-up (1986-2010). They found that serum $25(\mathrm{OH}) \mathrm{D}_{3}$ concentrations were not associated with the mortality of upper gastrointestinal cancer in Chinese population. Similarly, Pelucchi [53] and Chen [56] did not find a significant relationship between dietary intake of vitamin $\mathrm{D}$ and risk of gastric cancer. However, another study [57] reported a non-statistically significant but suggestive inverse relationship between vitamin $\mathrm{D}$ status and risk of gastric cancer. In particular, the Cohort Consortium Vitamin D Pooling Project of Rarer Cancers (VDPP) brought together 10 cohorts to conduct a prospective study of the association between vitamin $\mathrm{D}$ status and upper gastrointestinal cancers. In multivariate adjusted models, circulating $25(\mathrm{OH}) \mathrm{D}_{3}$ concentrations were not significantly associated with the risk of upper gastrointestinal cancer, but higher concentrations of $25(\mathrm{OH}) \mathrm{D}(>100 \mathrm{nmol} / \mathrm{L})$ were inversely associated with the risk of gastric cancer (OR:0.65, 95\% CI 0.26-1.62) [57]. However, some studies found a positive association between vitamin D and the risk of gastric cancer [52, 58]. Such as in a case-control study from Italy [52], a significant positive association was reported between vitamin D intake and the risk of gastric cancer (OR: 1.35, 95\% CI: $1.00-1.83$ ).

On the contrary, some studies support the notion of vitamin D-reduced the incidence and mortality of gastric cancer [54-56]. A retrospective case-control study revealed that the prevalence of vitamin D deficiency in gastric adenocarcinoma group was significantly higher than that in the control group (OR: 3.8, 95\% CI:1.4210.18, P:0.0079), suggesting a positive correlation between vitamin $\mathrm{D}$ deficiency and incidence of gastric adenocarcinoma [59]. A Health Professionals FollowUp study found an increment of $25 \mathrm{nmol} / \mathrm{L}$ in predicted $25(\mathrm{OH}) \mathrm{D}_{3}$ level was associated with a $17 \%$ reduction in total cancer incidence, a $29 \%$ reduction in total cancer mortality, and a $45 \%$ reduction in digestive cancer mortality, particularly in gastric cancer. It was therefore recommended that at least $1500 \mathrm{IU} /$ day may be necessary for the vitamin D supplementation to prevent digestive cancer mortality [60]. Ren [61] also reported an inverse association of serum $25(\mathrm{OH}) \mathrm{D}_{3}$ concentrations with clinical stage and lymph node metastasis of gastric cancer, suggesting that serum vitamin $\mathrm{D}$ level is a significant independent prognostic factor and vitamin D deficiency is associated with poor prognosis in gastric cancer.

As mentioned earlier, dietary vitamin $\mathrm{D}$ intake is a minimum source for the levels of circulating serum vitamin D since only $3 \mathrm{ng} / \mathrm{mL}$ differences were found in measured serum vitamin $\mathrm{D}$ between high and low dietary intake [62]. Besides, serum vitamin D status in most studies were based on one-time blood collection only, it is obvious that a single measurement of serum vitamin $\mathrm{D}$ cannot reflect real exposure to vitamin $\mathrm{D}$ in an etiologically relevant period. Even more, vitamin $\mathrm{D}$ status not just refer $25(\mathrm{OH}) \mathrm{D}_{3}$ but include $1 \alpha, 25(\mathrm{OH})_{2} \mathrm{D}_{3}$ and vitamin D binding to DBP since a very little vitamin $\mathrm{D}$ circulates as a free form of $25(\mathrm{OH}) \mathrm{D}_{3}$ [63]. All these may make an inconsistent relationship between vitamin $\mathrm{D}$ status and gastric cancer.

\section{Vitamin D receptor in gastric cancer}

The biological function of vitamin D, especially its anticancer effects, are largely through activation of VDR $[64,65]$, which is required to suppress tumorigenesis and may be a new target for cancer chemoprevention and/or chemotherapy [66]. It has been reported that a higher VDR expression is associated with reduced mortality, favorable tumor characteristics and an improved prognosis in breast, prostate and colon cancer [67-70]. One study from China [71] reported similar results that VDR expression was significantly lower in gastric cancer tissues, and that among cancer tissues VDR was higher expressed in well and moderate differentiated tissues and in small tumors, indicating that VDR could be a prognostic factor for gastric cancer.

Most VDR gen polymorphisms were identified since 1997 [72], and about six gen polymorphisms were found to be associated with cancers [73-75]. A casecontrol study [76] revealed a strong relationship between VDR TaqI(T/T) and the susceptibility of Chinese Han population to gastric cancer. Another study in Chinese Han population [77] revealed the patients of gastric cancer with the $f$ allele $(\mathrm{F} f+f f)$ had higher risk of a poorly differentiated type of gastric cancer. This finding has been reproduced in Uygur [78].

\section{Vitamin D binding protein in gastric cancer}

Vitamin D binding protein (DBP), a key protein in vitamin $\mathrm{D}$ metabolism, also mediates the biological function of vitamin D [79]. Several studies [80] have investigated serum DBP levels and DBP polymorphisms in association with cancer risk. Humphries [81] has validated DBP as one of the novel biomarkers of human gastric cancer. Two common coding single nucleotide polymorphisms (SNP) were identified in DBP gene, Glu416Asp (rs7041) and Thr420Lys (rs4588) [82]. Zhou [83]found that DBP Thr420Lys and Glu416Asp polymorphism had significant impact on the risk of developing gastrointestinal cancers in Chinese population. So far, the evidence is too little to confirm the relationship between DBP and gastric cancer, but it sheds some light to further study on DBP in gastric cancer. 


\section{VITAMIN D/VDR AND GASTRIC CANCER: LABORATORIAL RESEARCH}

\section{Vitamin D in animal models of gastric cancer}

The anti-tumor effects of vitamin $\mathrm{D}$ have been extensively studied in animal models. Since vitamin $\mathrm{D}$ has the side effect of hypercalcemia, its analogs are widely used. Hiroki [84] found that $1 \alpha(\mathrm{OH}) \mathrm{D}_{3}$, a synthetic analogue of vitamin $\mathrm{D}_{3}$, markedly inhibited the inductions of ornithine decarboxylase (ODC) activity by promoters of carcinogenesis in the stomach, suggesting an antitumor effect of vitamin $\mathrm{D}$ on gastric carcinogenesis. Vitamin $\mathrm{D}$ analogue $1 \alpha(\mathrm{OH}) \mathrm{D}_{3}$ largely reduced the incidence of gastrointestinal tumors induced by N-methyl$\mathrm{N}$-nitro-N-nitrosoguanidine in male Wistar rats [85]. 24R, 25-dihydroxyvitamind $\mathrm{D}_{3}$, a vitamin $\mathrm{D}_{3}$ derivative, also had chemopreventive effects on glandular stomach carcinogenesis in rats possibly by influencing calcium pharmacodynamics [86]. All of these results suggest that vitamin $\mathrm{D}$ and its analogs can inhibit the occurrence and development of gastric cancer in animal models.

\section{Vitamin D regulation of specific signaling pathways in gastric cancer cells}

Although abundant evidences from epidemical studies and animal models suggest vitamin D could obviously inhibit gastric cancer in vivo, its antitumor mechanisms are unclear. Some evidence indicate that vitamin D could block cell cycle, induce apoptosis and inhibit cell invasion and metastasis (Figure 2.) [87, 88].

Selective inhibitors of mammalian DNA polymerase $\alpha$, vitamin $\mathrm{D}_{2}$ and $\mathrm{D}_{3}$ could halt NUGC-3 human gastric cancer cells at the G1 phase in the cell cycle [89]. Park [90] found that 19-nor-1,25-dihydroxyvitamin $\mathrm{D}_{2}$, a vitamin D analog, could block cell cycle of MKN45 gastric cancer cells by decreasing the expression of cyclindependent kinase(CDK), CDK2, CDK4, CDK6 and Cyclin D1. Functional VDR elements have been identified in the promoter of PTEN, suggesting that vitamin D may play a role in the regulation of PTEN expression as a nuclear transcription factor [91]. A study [92] demonstrated that vitamin D induced apoptosis through PTEN upregulation in HGC-27 gastric cancer cells, and that vitamin D receptor, Egr-1 and p300 induced PTEN expression in a synergistic fashion. Another study indicated that EB1089, a vitamin D analog induced gastric cancer cells apoptosis through a VDR and mitochondrial apoptosis pathway, which was blocked by treating the cells with VDR siRNA or butin, an inhibitor of the mitochondrial apoptosis pathway [93].

Since Hedgehog signaling pathway plays an important role in the pathogenesis and the prognosis of gastric cancer, targeting this pathway is a new potential therapeutic opportunity in gastric cancer [94]. Vitamin $\mathrm{D}_{3}$ may act as an antagonist of hedgehog signaling to suppress viability of gastric cancer cells, and it also has a synergistic effect with other anticancer drugs by reducing mRNA expression of the target genes of hedgehog signaling ( Ptch1, Gli1, cyclin D1 and bcl2) [95]. Co-treatment with cisplatin and $1 \alpha, 25(\mathrm{OH})_{2} \mathrm{D}_{3}$ enhanced cisplatin-mediated cell growth inhibition and cell apoptosis of human gastric cancer cells with an upregulation of Bax, a decrease in ERK and AKT phosphorylation levels, and an increase in p21 and p27 levels [96].

\section{Vitamin D up-protein1}

Vitamin $\mathrm{D}_{3}$ upregulated protein 1 (VDUP1) is a 46 $\mathrm{kDa}$ protein upregulated by $1 \alpha, 25(\mathrm{OH})_{2} \mathrm{D}_{3}$ [97]. VDUP1 has an antitumor activity by forming a transcriptional repressor complex, which induced cell-cycle arrest at the G0/G1 phase and suppressed cell invasiveness and tumor metastasis [98, 99]. In clinic, VDUP1 expression is significantly lower in gastric cancer tissue than in their adjacent normal tissue and the downregulation of VDUP1 expression is associated with poor prognosis [100]. Kwon [101] found that VDUP1 negatively regulates Helicobacter pylori-associated gastric carcinogenesis in mice by disrupting cell growth and inhibiting the induction of TNFa, NF-kB and COX-2, suggesting that VDUP1 may serve as a potential target for the development of anticancer agents for gastric cancer.

\section{Viatmin D with H. pylori and microRNA}

Helicobacter pylori (Hp) infection plays an important pathogenic role in most gastric cancer cases [102, 103]. International Agency for Research on Cancer (IARC) classified $H p$ as a group 1 carcinogen in 1994, and reconfirmed this classification in 2009 [2]. A crosssectional study found a significant positive correlation between the levels of serum $25-\mathrm{OH}$ vitamin $\mathrm{D}$ and serum $H p$ specific $\mathrm{IgG}$ antibody titers, indicating that vitamin D analog may have antibacterial action against $H p$ [104]. Kouichi Hosoda [105] further confirmed Vitamin $\mathrm{D}_{3}$ decomposition product (VDP1) can exert an antibacterial action against $H p$ by inducing a collapse of cell membrane structures of $\mathrm{Hp}$ and ultimately lysing the bacterial cells. These findings suggest that VDP1 may become a new antibacterial substance against $H p$.

MicroRNAs (miRNAs) are short, single strands of noncoding RNA with important functions in mRNA translation and regulation of cell cycle and apoptosis [106]. It was reported that miR145 induced by $1 \alpha$, $25(\mathrm{OH})_{2} \mathrm{D}_{3}$ through VDR could inhibit colony formation, gastric cancer cell viability and induce cell arrest at S-phase by targeting E2F3 and CDK6. This might hold 
promise for prognosis and therapeutic strategies for gastric cancer [107].

\section{Vitamin D/VDR in immunity}

In the last few years, accumulating evidence indicates an important modulatory role of vitamin D/VDR in adaptive and innate immune cells [108-110], which is distinct from their classical anti-tumor roles. After identification of VDR in series immune cells, numerous cellular and molecular targets of VDR in the immune system have been elaborated $[111,112]$. VDR regulates all stages of a $\mathrm{T}$ cells life, ranging from development to differentiation and elicitation of effector functions [113]. Likewise, VDR is essential for Th2 cell function, and vitamin $\mathrm{D}$ could increase the activities of regulatory $\mathrm{T}$ cells and Th2 cells while suppressing Th1 cell activity $[114,115]$. In antigen-presenting cells, vitamin D is believed to program dendritic cells (DC) for tolerance, dampen their ability to activate effector T-cell generation, and enhance their potential to induce anti-inflammatory regulatory $\mathrm{T}$ (Treg) cells. Vitamin D also interacts with DC to influence their migration and their capacity to instruct $\mathrm{T}$ cells and hence to initiate, fine tune or dampen immune reactions [116]. On the other hand, vitamin D-treated DCs are significantly more potent in driving differentiation of IL-22-producing $\mathrm{T}$ cells and are markedly enhanced to secrete TNF- $\alpha$, IL-6, IL-1 $\beta$ and IL-23 [117]. However, despite compelling evidence for the roles of vitamin $\mathrm{D} /$ VDR in immunity, there are no studies on vitamin D/VDR in gastric cancer immunity.

\section{Vitamin D and gastric cancer: clinical trial}

To date, it is scarce for the clinical trial directly exploring vitamin D to potentially treat gastric cancer [118, 119]. In a 4 year, population-based, double-blind, randomized placebo-controlled trial [119], Joan et al. found that the relative risk of developing cancer was 0.232 for the calcium plus vitamin D group and 0.587 for the calcium alone group, and that serum 25-hydroxyvitamin D concentrations were significant, independent predictors of cancer risk. As $H p$ is regarded as an independent risk factor of gastric cancer, Kawaura et al. [118] tested whether long term $1 \alpha(\mathrm{OH}) \mathrm{D}_{3}$ administration could inhibit $H p$ infection, and they found that $H p$ infection rate was significantly lower in subjects with $1 \alpha(\mathrm{OH}) \mathrm{D}_{3}$ treatment than those without treatment. This study reconfirms vitamin $\mathrm{D}$ analog has antibacterial action against $H p$.

\section{CONCLUSIONS}

Vitamin D has received extensive attention in recent years, especially after Mark [120] found vitamin D could promote protein homeostasis and longevity in nematodes. Most current evidence suggests that vitamin $\mathrm{D}$ is inversely associated with the morbidity and mortality of gastric cancer. Not only laboratorial studies at the levels of cells, tissues and animal models but also clinical trial support an anti-cancer role of vitamin D. However, the epidemiological data are still paradoxical. The studies utilizing ultraviolet B exposure as a main measurement consistently show the increased risk of gastric cancer with vitamin D deficiency, but some studies measuring serum $25(\mathrm{OH}) \mathrm{D}_{3}$ levels in human body do not support this notion. As discussed above, imprecise and inconsecutive assessment of serum vitamin D status may lead to the obscure relationship between $25(\mathrm{OH}) \mathrm{D}_{3}$ levels and gastric cancer risk. The laboratorial studies demonstrate that vitamin D and its metabolites activate VDR to inhibit viability, proliferation and metastasis of gastric cancer cells, and also explore the underlying molecular mechanisms against gastric tumorigenesis and progression. Furthermore, vitamin D metabolites or analogues might also inhibit $H p$ infection and $H p$ associated gastric cancer. Although basic research supports the protective effects of vitamin D against gastric cancer, further studies are needed to elucidate its anti-tumour mechanisms, especial its interaction with VDR. At last but not least, large-scale and long-term clinical randomized controlled trials (RCTs) are necessary to make a definite conclusion whether vitamin $\mathrm{D}$ can really offer preventive and/or therapeutic benefits to gastric cancer.

\section{Abbreviations}

VDR: vitamin D receptor; $1 \alpha, 25(\mathrm{OH})_{2} \mathrm{D}_{3}: 1 \alpha, 25-$ dihydroxyvitamin $\mathrm{D} ; 25(\mathrm{OH}) \mathrm{D}_{3}$ : 25-hydroxyvitamin $\mathrm{D}$; UVB: Ultraviolet B; DBP: Vitamin D binding protein; VDUP1: Vitamin D3 upregulated protein 1; PTEN: phosphatase and tensin homolog deleted on chromosome 10; Hp: Helicobacter pylori; DC: dendritic cell.

\section{ACKNOWLEDGMENTS}

This study was supported by The National Key Research and Development Program of China (No. 2016YFC1302200) and the National Natural Science Foundation of China (No. 31371167 and No. 81570477) to HD.

\section{CONFLICTS OF INTEREST}

The authors declare no conflict of interest.

\section{REFERENCES}

1. Van Cutsem E, Sagaert X, Topal B, Haustermans K, Prenen H. Gastric cancer. Lancet. 2016; 388:2654-64.

2. Helicobacter pylori Eradication as a Strategy for Preventing 
Gastric Cancer. Lyon, France: International Agency for Research on Cancer. IARC Helicobacter Pylori Working Group. 2014.

3. Van Cutsem E, Dicato M, Geva R, Arber N, Bang Y, Benson A, Cervantes A, Diaz-Rubio E, Ducreux M, Glynne-Jones R, Grothey A, Haller D, Haustermans K, et al. The diagnosis and management of gastric cancer: expert discussion and recommendations from the 12th ESMO/ World Congress on Gastrointestinal Cancer, Barcelona, 2010. Ann Oncol. 2011; 22 Suppl 5:v1-9.

4. Badgwell B. Multimodality Therapy of Localized Gastric Adenocarcinoma. J Natl Compr Canc Netw. 2016; 14:1321-27.

5. Marqués-Lespier JM, González-Pons M, Cruz-Correa M. Current Perspectives on Gastric Cancer. Gastroenterol Clin North Am. 2016; 45:413-28.

6. Bouillon R, Suda T. Vitamin D: calcium and bone homeostasis during evolution. Bonekey Rep. 2014; 3:480.

7. Garland CF, Garland FC. Do sunlight and vitamin D reduce the likelihood of colon cancer? Int J Epidemiol. 1980; 9:227-31.

8. Barreto SG, Neale RE. Vitamin D and pancreatic cancer. Cancer Lett. 2015; 368:1-6.

9. Burns EM, Elmets CA, Yusuf N. Vitamin D and skin cancer. Photochem Photobiol. 2015; 91:201-09.

10. Hargrove L, Francis T, Francis H. Vitamin D and GI cancers: shedding some light on dark diseases. Ann Transl Med. 2014; 2:9.

11. Shao T, Klein P, Grossbard ML. Vitamin D and breast cancer. Oncologist. 2012; 17:36-45.

12. Krajewski W, Dzięgała M, Kołodziej A, Dembowski J, Zdrojowy R. Vitamin D and urological cancers. Cent European J Urol. 2016; 69:139-47.

13. Yee YK, Chintalacharuvu SR, Lu J, Nagpal S. Vitamin D receptor modulators for inflammation and cancer. Mini Rev Med Chem. 2005; 5:761-78.

14. Haussler MR, Whitfield GK, Haussler CA, Hsieh JC, Thompson PD, Selznick SH, Dominguez CE, Jurutka PW. The nuclear vitamin D receptor: biological and molecular regulatory properties revealed. J Bone Miner Res. 1998; 13:325-49.

15. Feldman D, Krishnan AV, Swami S, Giovannucci E, Feldman BJ. The role of vitamin D in reducing cancer risk and progression. Nat Rev Cancer. 2014; 14:342-57.

16. Fleet JC, DeSmet M, Johnson R, Li Y. Vitamin D and cancer: a review of molecular mechanisms. Biochem J. 2012; 441:61-76.

17. McCollum EV. An experimental demonstration of the existence of a vitamin which promotes calcium deposition. J Biol Chem. 1922; 53:293-98.

18. DeLuca HF. Overview of general physiologic features and functions of vitamin D. Am J Clin Nutr. 2004; 80:1689S-96S.
19. Souberbielle JC, Maruani G, Courbebaisse M. [Metabolism and main effects of vitamin D]. [Article in French]. Presse Med. 2013; 42:1343-50.

20. Holick MF. Vitamin D deficiency. N Engl J Med. 2007; 357:266-81.

21. Holick MF. Resurrection of vitamin D deficiency and rickets. J Clin Invest. 2006; 116:2062-72.

22. Lamberg-Allardt C. Vitamin D in foods and as supplements. Prog Biophys Mol Biol. 2006; 92:33-38.

23. Prosser DE, Jones G. Enzymes involved in the activation and inactivation of vitamin D. Trends Biochem Sci. 2004; 29:664-73.

24. Christakos S, Dhawan P, Verstuyf A, Verlinden L, Carmeliet G, Vitamin D. Vitamin D: Metabolism, Molecular Mechanism of Action, and Pleiotropic Effects. Physiol Rev. 2016; 96:365-408.

25. Okano T. [The role of the liver in vitamin D metabolism]. [Article in Japanese]. Clin Calcium. 2015; 25:1613-18.

26. Henry HL. Regulation of vitamin D metabolism. Best Pract Res Clin Endocrinol Metab. 2011; 25:531-41.

27. Heikkinen S, Väisänen S, Pehkonen P, Seuter S, Benes V, Carlberg C. Nuclear hormone 1 $\alpha, 25$-dihydroxyvitamin D3 elicits a genome-wide shift in the locations of VDR chromatin occupancy. Nucleic Acids Res. 2011; 39:918193.

28. Yang L, Ma J, Zhang X, Fan Y, Wang L. Protective role of the vitamin D receptor. Cell Immunol. 2012; 279:160-66.

29. Haussler MR, Jurutka PW, Mizwicki M, Norman AW. Vitamin D receptor (VDR)-mediated actions of $1 \alpha, 25(\mathrm{OH})-$ vitamin D3: genomic and non-genomic mechanisms. Best Pract Res Clin Endocrinol Metab. 2011; 25:543-59.

30. Norman AW, Bouillon R, Farach-Carson MC, Bishop JE, Zhou LX, Nemere I, Zhao J, Muralidharan KR, Okamura WH. Demonstration that 1 beta,25-dihydroxyvitamin D3 is an antagonist of the nongenomic but not genomic biological responses and biological profile of the three A-ring diastereomers of 1 alpha,25-dihydroxyvitamin D3. J Biol Chem. 1993; 268:20022-30.

31. Kajikawa M, Ishida H, Fujimoto S, Mukai E, Nishimura M, Fujita J, Tsuura Y, Okamoto Y, Norman AW, Seino Y. An insulinotropic effect of vitamin D analog with increasing intracellular $\mathrm{Ca} 2+$ concentration in pancreatic beta-cells through nongenomic signal transduction. Endocrinology. 1999; 140:4706-12.

32. Menegaz D, Barrientos-Duran A, Kline A, Silva FR, Norman AW, Mizwicki MT, Zanello LP. 1alpha,25(OH)2Vitamin D3 stimulation of secretion via chloride channel activation in Sertoli cells. J Steroid Biochem Mol Biol. 2010; 119:127-34.

33. Zanello LP, Norman AW. Rapid modulation of osteoblast ion channel responses by 1alpha,25(OH)2-vitamin D3 requires the presence of a functional vitamin $\mathrm{D}$ nuclear receptor. Proc Natl Acad Sci USA. 2004; 101:1589-94.

34. Rebsamen MC, Sun J, Norman AW, Liao JK. 1alpha,25- 
dihydroxyvitamin D3 induces vascular smooth muscle cell migration via activation of phosphatidylinositol 3-kinase. Circ Res. 2002; 91:17-24.

35. Trowbridge R, Mittal SK, Agrawal DK. Vitamin D and the epidemiology of upper gastrointestinal cancers: a critical analysis of the current evidence. Cancer Epidemiol Biomarkers Prev. 2013; 22:1007-14.

36. Grant WB. Ecological studies of the UVB-vitamin D-cancer hypothesis. Anticancer Res. 2012; 32:223-36.

37. Grant WB. Does solar ultraviolet irradiation affect cancer mortality rates in China? Asian Pac J Cancer Prev. 2007; $8: 236-42$.

38. Grant WB, Boucher BJ. Current impediments to acceptance of the ultraviolet-B-vitamin D-cancer hypothesis. Anticancer Res. 2009; 29:3597-604.

39. Grant WB. The likely role of vitamin D from solar ultraviolet-B irradiance in increasing cancer survival. Anticancer Res. 2006; 26:2605-14.

40. Chen W, Armstrong BK, Rahman B, Zheng R, Zhang S, Clements M. Relationship between cancer survival and ambient ultraviolet B irradiance in China. Cancer Causes Control. 2013; 24:1323-30.

41. Boscoe FP, Schymura MJ. Solar ultraviolet-B exposure and cancer incidence and mortality in the United States, 19932002. BMC Cancer. 2006; 6:264.

42. Mizoue T. Ecological study of solar radiation and cancer mortality in Japan. Health Phys. 2004; 87:532-38.

43. Chen W, Clements M, Rahman B, Zhang S, Qiao Y, Armstrong BK. Relationship between cancer mortality/ incidence and ambient ultraviolet B irradiance in China. Cancer Causes Control. 2010; 21:1701-09.

44. Grant WB. An ecological study of cancer mortality rates in the United States with respect to solar ultraviolet-B doses, smoking, alcohol consumption and urban/rural residence. Dermatoendocrinol. 2010; 2:68-76.

45. Grant WB. An estimate of premature cancer mortality in the U.S. due to inadequate doses of solar ultraviolet-B radiation. Cancer. 2002; 94:1867-75.

46. Grant WB. Lower vitamin-D production from solar ultraviolet-B irradiance may explain some differences in cancer survival rates. J Natl Med Assoc. 2006; 98:357-64.

47. Tuohimaa P, Pukkala E, Scélo G, Olsen JH, Brewster DH, Hemminki K, Tracey E, Weiderpass E, Kliewer EV, Pompe-Kirn V, McBride ML, Martos C, Chia KS, et al. Does solar exposure, as indicated by the non-melanoma skin cancers, protect from solid cancers: vitamin D as a possible explanation. Eur J Cancer. 2007; 43:1701-12.

48. Grant WB. An ecologic study of cancer mortality rates in Spain with respect to indices of solar UVB irradiance and smoking. Int J Cancer. 2007; 120:1123-28.

49. Lindelöf B, Krynitz B, Ayoubi S, Martschin C, WieglebEdström D, Wiklund K. Previous extensive sun exposure and subsequent vitamin $\mathrm{D}$ production in patients with basal cell carcinoma of the skin, has no protective effect on internal cancers. Eur J Cancer. 2012; 48:1154-58.

50. Grant WB. How strong is the evidence that solar ultraviolet $\mathrm{B}$ and vitamin $\mathrm{D}$ reduce the risk of cancer?: an examination using Hill's criteria for causality. Dermatoendocrinol. 2009; 1:17-24.

51. Cornée J, Pobel D, Riboli E, Guyader M, Hémon B. A case-control study of gastric cancer and nutritional factors in Marseille, France. Eur J Epidemiol. 1995; 11:55-65.

52. La Vecchia C, Ferraroni M, D’Avanzo B, Decarli A, Franceschi S. Selected micronutrient intake and the risk of gastric cancer. Cancer Epidemiol Biomarkers Prev. 1994; 3:393-98.

53. Pelucchi C, Tramacere I, Bertuccio P, Tavani A, Negri E, La Vecchia C. Dietary intake of selected micronutrients and gastric cancer risk: an Italian case-control study. Ann Oncol. 2009; 20:160-65.

54. Mayne ST, Risch HA, Dubrow R, Chow WH, Gammon MD, Vaughan TL, Farrow DC, Schoenberg JB, Stanford JL, Ahsan H, West AB, Rotterdam H, Blot WJ, Fraumeni JF Jr. Nutrient intake and risk of subtypes of esophageal and gastric cancer. Cancer Epidemiol Biomarkers Prev. 2001; 10:1055-62.

55. Lin SW, Chen W, Fan JH, Dawsey SM, Taylor PR, Qiao YL, Abnet CC. Prospective study of serum 25-hydroxyvitamin D concentration and mortality in a Chinese population. Am J Epidemiol. 2012; 176:1043-50.

56. Chen W, Dawsey SM, Qiao YL, Mark SD, Dong ZW, Taylor PR, Zhao P, Abnet CC. Prospective study of serum 25(OH)-vitamin D concentration and risk of oesophageal and gastric cancers. Br J Cancer. 2007; 97:123-28.

57. Abnet CC, Chen Y, Chow WH, Gao YT, Helzlsouer KJ, Le Marchand L, McCullough ML, Shikany JM, Virtamo J, Weinstein SJ, Xiang YB, Yu K, Zheng W, et al. Circulating 25-hydroxyvitamin $\mathrm{D}$ and risk of esophageal and gastric cancer: Cohort Consortium Vitamin D Pooling Project of Rarer Cancers. Am J Epidemiol. 2010; 172:94-106.

58. Fidan E, Yildiz B, Yilmaz M, Ozdemir F, Kavgaci H, Aydin F. Increased Circulating Vitamin D and Testosterone Levels in Patients with Cancer. HEALTHMED. 2010; 41:1072-75.

59. Vyas N, Companioni RC, Tiba M, Alkhawam H, Catalano C, Sogomonian R, Baum J, Walfish A. Association between serum vitamin $\mathrm{D}$ levels and gastric cancer: A retrospective chart analysis. World J Gastrointest Oncol. 2016; 8:688-94.

60. Giovannucci E, Liu Y, Rimm EB, Hollis BW, Fuchs CS, Stampfer MJ, Willett WC. Prospective study of predictors of vitamin D status and cancer incidence and mortality in men. J Natl Cancer Inst. 2006; 98:451-59.

61. Ren C, Qiu MZ, Wang DS, Luo HY, Zhang DS, Wang ZQ, Wang FH, Li YH, Zhou ZW, Xu RH. Prognostic effects of 25-hydroxyvitamin D levels in gastric cancer. J Transl Med. 2012; 10:16.

62. Bertrand KA, Giovannucci E, Liu Y, Malspeis S, Eliassen $\mathrm{AH}, \mathrm{Wu} \mathrm{K}$, Holmes MD, Laden F, Feskanich D. Determinants of plasma 25-hydroxyvitamin D and 
development of prediction models in three US cohorts. Br J Nutr. 2012; 108:1889-96.

63. Speeckaert M, Huang G, Delanghe JR, Taes YE. Biological and clinical aspects of the vitamin D binding protein (Gcglobulin) and its polymorphism. Clin Chim Acta. 2006; 372:33-42.

64. Thorne J, Campbell MJ. The vitamin D receptor in cancer. Proc Nutr Soc. 2008; 67:115-27.

65. Deeb KK, Trump DL, Johnson CS. Vitamin D signalling pathways in cancer: potential for anticancer therapeutics. Nat Rev Cancer. 2007; 7:684-700.

66. Zinser GM, Suckow M, Welsh J. Vitamin D receptor (VDR) ablation alters carcinogen-induced tumorigenesis in mammary gland, epidermis and lymphoid tissues. J Steroid Biochem Mol Biol. 2005; 97:153-64.

67. Hendrickson WK, Flavin R, Kasperzyk JL, Fiorentino M, Fang F, Lis R, Fiore C, Penney KL, Ma J, Kantoff PW, Stampfer MJ, Loda M, Mucci LA, Giovannucci E. Vitamin $\mathrm{D}$ receptor protein expression in tumor tissue and prostate cancer progression. J Clin Oncol. 2011; 29:2378-85.

68. Berger U, McClelland RA, Wilson P, Greene GL, Haussler MR, Pike JW, Colston K, Easton D, Coombes RC. Immunocytochemical determination of estrogen receptor, progesterone receptor, and 1,25-dihydroxyvitamin D3 receptor in breast cancer and relationship to prognosis. Cancer Res. 1991; 51:239-44.

69. Ditsch N, Toth B, Mayr D, Lenhard M, Gallwas J, Weissenbacher T, Dannecker C, Friese K, Jeschke U. The association between vitamin $\mathrm{D}$ receptor expression and prolonged overall survival in breast cancer. J Histochem Cytochem. 2012; 60:121-29.

70. Ferrer-Mayorga G, Gómez-López G, Barbáchano A, Fernández-Barral A, Peña C, Pisano DG, Cantero R, Rojo F, Muñoz A, Larriba MJ. Vitamin D receptor expression and associated gene signature in tumour stromal fibroblasts predict clinical outcome in colorectal cancer. Gut. 2016 Apr 6. pii: gutjnl-2015-310977. doi: 10.1136/ gutjnl-2015-310977. [Epub ahead of print].

71. Wen Y, Da M, Zhang Y, Peng L, Yao J, Duan Y. Alterations in vitamin $\mathrm{D}$ signaling pathway in gastric cancer progression: a study of vitamin $\mathrm{D}$ receptor expression in human normal, premalignant, and malignant gastric tissue. Int J Clin Exp Pathol. 2015; 8:13176-84.

72. Ingles SA, Ross RK, Yu MC, Irvine RA, La Pera G, Haile RW, Coetzee GA. Association of prostate cancer risk with genetic polymorphisms in vitamin $\mathrm{D}$ receptor and androgen receptor. J Natl Cancer Inst. 1997; 89:166-70.

73. Yang B, Liu S, Yang X, Wang Y, Zhao X, Zheng D, Gao J, Chen K, Gao Y, Liu L, Ren H, Wang W, Qi Y, Yu G. Current evidence on the four polymorphisms of VDR and breast cancer risk in Caucasian women. Meta Gene. 2013; 2:41-49.

74. Zhao XZ, Yang BH, Yu GH, Liu SZ, Yuan ZY. Polymorphisms in the vitamin D receptor (VDR) genes and skin cancer risk in European population: a meta-analysis. Arch Dermatol Res. 2014; 306:545-53.

75. Takeshige N, Yin G, Ohnaka K, Kono S, Ueki T, Tanaka M, Maehara Y, Okamura T, Ikejiri K, Maekawa T, Yasunami Y, Takenaka K, Ichimiya H, Terasaka R. Associations between vitamin D receptor (VDR) gene polymorphisms and colorectal cancer risk and effect modifications of dietary calcium and vitamin D in a Japanese population. Asian Pac J Cancer Prev. 2015; 16:2019-26.

76. Shen XB, Wang J, Li PF, Ren XF, Yan XL, Wang F. Screening of susceptibility genes and multi-gene risk analysis in gastric cancer. Med Oncol. 2014; 31:196.

77. Cong L, Wang WB, Liu Q, Du JJ, Fok I. FokI Polymorphism of the Vitamin D Receptor Gene Is Associated with Susceptibility to Gastric Cancer: A CaseControl Study. Tohoku J Exp Med. 2015; 236:219-24.

78. Fang F, Gao J, Han F, Wang HJ. [Correlation of gastric cancer and effects of vitamin $\mathrm{D}$ receptor gene FokI polymorphism on C-reactive protein and D-dimer in Uygur nationality patients]. [Article in Chinese]. Zhonghua Yi Xue Za Zhi. 2016; 96:2541-44.

79. Speeckaert M, Huang G, Delanghe JR, Taes YE. Biological and clinical aspects of the vitamin D binding protein (Gcglobulin) and its polymorphism. Clin Chim Acta. 2006; 372:33-42.

80. Tagliabue E, Raimondi S, Gandini S. Meta-analysis of vitamin D-binding protein and cancer risk. Cancer Epidemiol Biomarkers Prev. 2015; 24:1758-65.

81. Humphries JM, Penno MA, Weiland F, Klingler-Hoffmann M, Zuber A, Boussioutas A, Ernst M, Hoffmann P. Identification and validation of novel candidate protein biomarkers for the detection of human gastric cancer. Biochim Biophys Acta. 2014; 1844:1051-58.

82. Sinotte M, Diorio C, Bérubé S, Pollak M, Brisson J. Genetic polymorphisms of the vitamin $\mathrm{D}$ binding protein and plasma concentrations of 25-hydroxyvitamin D in premenopausal women. Am J Clin Nutr. 2009; 89:634-40.

83. Zhou L, Zhang X, Chen X, Liu L, Lu C, Tang X, Shi J, Li M, Zhou M, Zhang Z, Xiao L, Yang M. GC Glu416Asp and Thr420Lys polymorphisms contribute to gastrointestinal cancer susceptibility in a Chinese population. Int J Clin Exp Med. 2012; 5:72-79.

84. Hashiba H, Fukushima M, Chida K, Kuroki T. Systemic inhibition of tumor promoter-induced ornithine decarboxylase in 1 alpha-hydroxyvitamin D3-treated animals. Cancer Res. 1987; 47:5031-35.

85. Kawaura A, Tanida N, Nishikawa M, Yamamoto I, Sawada K, Tsujiai T, Kang KB, Izumi K. Inhibitory effect of 1alpha-hydroxyvitamin D3 on N-methyl-N'-nitro-Nnitrosoguanidine-induced gastrointestinal carcinogenesis in Wistar rats. Cancer Lett. 1998; 122:227-30.

86. Ikezaki S, Nishikawa A, Furukawa F, Tanakamura Z, Kim HC, Mori H, Takahashi M. Chemopreventive effects of 24R,25-dihydroxyvitamin D3, a vitamin D3 derivative, 
on glandular stomach carcinogenesis induced in rats by N-methyl-N'-nitro-N-nitrosoguanidine and sodium chloride. Cancer Res. 1996; 56:2767-70.

87. Bao A, Li Y, Tong Y, Zheng H, Wu W, Wei C. Tumorsuppressive effects of 1, 25-dihydroxyvitamin D3 in gastric cancer cells. Hepatogastroenterology. 2013; 60:943-48.

88. Zhang L, Wang L, Wu X. [Effects of 1,25(OH)(2)D(3) on SGC-7901 cell proliferation and tumor necrosis factor-- $\alpha 1$; expression]. [Article in Chinese]. Nan Fang Yi Ke Da Xue Xue Bao. 2012; 32:710-13.

89. Mizushina Y, Xu X, Murakami C, Okano T, Takemura M, Yoshida H, Sakaguchi K. Selective inhibition of mammalian DNA polymerase alpha by vitamin D2 and D3. J Pharmacol Sci. 2003; 92:283-90.

90. Park MR, Lee JH, Park MS, Hwang JE, Shim HJ, Cho SH, Chung IJ, Bae WK. Suppressive effect of 19-nor-1 $\alpha-25$ dihydroxyvitamin D2 on gastric cancer cells and peritoneal metastasis model. J Korean Med Sci. 2012; 27:1037-43.

91. Hisatake J, O'Kelly J, Uskokovic MR, Tomoyasu S, Koeffler HP. Novel vitamin D(3) analog, 21-(3-methyl-3hydroxy-butyl)-19-nor $\mathrm{D}(3)$, that modulates cell growth, differentiation, apoptosis, cell cycle, and induction of PTEN in leukemic cells. Blood. 2001; 97:2427-33.

92. Pan L, Matloob AF, Du J, Pan H, Dong Z, Zhao J, Feng Y, Zhong Y, Huang B, Lu J. Vitamin D stimulates apoptosis in gastric cancer cells in synergy with trichostatin A /sodium butyrate-induced and 5-aza-2'-deoxycytidine-induced PTEN upregulation. FEBS J. 2010; 277:989-99.

93. Wang W, Zhao CH, Zhang N, Wang J. Vitamin D analog EB1089 induces apoptosis in a subpopulation of SGC-7901 gastric cancer cells through a mitochondrial-dependent apoptotic pathway. Nutr Cancer. 2013; 65:1067-75.

94. Abdel-Rahman O. Hedgehog pathway aberrations and gastric cancer; evaluation of prognostic impact and exploration of therapeutic potentials. Tumour Biol. 2015; 36:1367-74.

95. Baek S, Lee YS, Shim HE, Yoon S, Baek SY, Kim BS, Oh SO. Vitamin D3 regulates cell viability in gastric cancer and cholangiocarcinoma. Anat Cell Biol. 2011; 44:204-09.

96. Bao A, Li Y, Tong Y, Zheng $\mathrm{H}$, Wu W, Wei C. 1,25-Dihydroxyvitamin D3 and cisplatin synergistically induce apoptosis and cell cycle arrest in gastric cancer cells. Int J Mol Med. 2014; 33:1177-84.

97. Chen KS, DeLuca HF. Isolation and characterization of a novel cDNA from HL-60 cells treated with 1,25-dihydroxyvitamin D-3. Biochim Biophys Acta. 1994; 1219:26-32.

98. Shin D, Jeon JH, Jeong M, Suh HW, Kim S, Kim HC, Moon OS, Kim YS, Chung JW, Yoon SR, Kim WH, Choi I. VDUP1 mediates nuclear export of HIF1alpha via CRM1-dependent pathway. Biochim Biophys Acta. 2008; 1783:838-48.

99. Han SH, Jeon JH, Ju HR, Jung U, Kim KY, Yoo HS, Lee YH, Song KS, Hwang HM, Na YS, Yang Y, Lee
KN, Choi I. VDUP1 upregulated by TGF-beta1 and 1,25-dihydorxyvitamin D3 inhibits tumor cell growth by blocking cell-cycle progression. Oncogene. 2003; 22:403546.

100. Ikarashi M, Takahashi Y, Ishii Y, Nagata T, Asai S, Ishikawa K. Vitamin D3 up-regulated protein 1 (VDUP1) expression in gastrointestinal cancer and its relation to stage of disease. Anticancer Res. 2002; 22:4045-48.

101. Kwon HJ, Won YS, Nam KT, Yoon YD, Jee H, Yoon WK, Nam KH, Kang JS, Han SU, Choi IP, Kim DY, Kim HC. Vitamin D3 upregulated protein 1 deficiency promotes $\mathrm{N}$-methyl-N-nitrosourea and Helicobacter pylori-induced gastric carcinogenesis in mice. Gut. 2012; 61:53-63.

102. Loor A, Dumitraşcu DL. Helicobacter pylori Infection, Gastric Cancer and Gastropanel. Rom J Intern Med. 2016; 54:151-56.

103. Fukase K, Kato M, Kikuchi S, Inoue K, Uemura N, Okamoto S, Terao S, Amagai K, Hayashi S, Asaka M; Japan Gast Study Group. Effect of eradication of Helicobacter pylori on incidence of metachronous gastric carcinoma after endoscopic resection of early gastric cancer: an open-label, randomised controlled trial. Lancet. 2008; 372:392-97.

104. Nasri H, Baradaran A. The influence of serum 25-hydroxy vitamin D levels on Helicobacter Pylori Infections in patients with end-stage renal failure on regular hemodialysis. Saudi J Kidney Dis Transpl. 2007; 18:21519.

105. Hosoda K, Shimomura H, Wanibuchi K, Masui H, Amgalanbaatar A, Hayashi S, Takahashi $\mathrm{T}$ and Hirai Y. Identification and characterization of a vitamin D-3 decomposition product bactericidal against Helicobacter pylori. SCI REP-UK. 2015; 5:8860.

106. Svoronos AA, Engelman DM, Slack FJ. OncomiR or Tumor Suppressor? The Duplicity of MicroRNAs in Cancer. Cancer Res. 2016; 76:3666-70.

107. Chang S, Gao L, Yang Y, Tong D, Guo B, Liu L, Li Z, Song T, Huang C. miR-145 mediates the antiproliferative and gene regulatory effects of vitamin D3 by directly targeting E2F3 in gastric cancer cells. Oncotarget. 2015; 6:7675-85. doi: 10.18632/oncotarget.3048

108. Hewison M. Vitamin D and immune function: an overview. Proc Nutr Soc. 2012; 71:50-61.

109. Miller J, Gallo RL. Vitamin D and innate immunity. Dermatol Ther (Heidelb). 2010; 23:13-22.

110. Hewison M. Vitamin D and the immune system: new perspectives on an old theme. Endocrinol Metab Clin North Am. 2010; 39:365-79.

111. Froicu M, Cantorna MT. Vitamin D and the vitamin D receptor are critical for control of the innate immune response to colonic injury. BMC Immunol. 2007; 8:5.

112. Korf H, Wenes M, Stijlemans B, Takiishi T, Robert S, Miani M, Eizirik DL, Gysemans C, Mathieu C. 1,25-Dihydroxyvitamin D3 curtails the inflammatory and $\mathrm{T}$ cell stimulatory capacity of macrophages through an IL-10- 
dependent mechanism. Immunobiology. 2012; 217:1292300 .

113. Kongsbak M, Levring TB, Geisler C, von Essen MR. The vitamin $\mathrm{d}$ receptor and $\mathrm{T}$ cell function. Front Immunol. 2013; 4:148.

114. Adorini L, Penna G, Giarratana N, Uskokovic M. Tolerogenic dendritic cells induced by vitamin $\mathrm{D}$ receptor ligands enhance regulatory $\mathrm{T}$ cells inhibiting allograft rejection and autoimmune diseases. J Cell Biochem. 2003; 88:227-33.

115. Froicu M, Weaver V, Wynn TA, McDowell MA, Welsh JE, Cantorna MT. A crucial role for the vitamin D receptor in experimental inflammatory bowel diseases. Mol Endocrinol. 2003; 17:2386-92.

116. Bscheider M, Butcher EC. Vitamin D immunoregulation through dendritic cells. Immunology. 2016; 148:227-36.

117. Sommer A, Fabri M, Vitamin D. Vitamin D regulates cytokine patterns secreted by dendritic cells to promote differentiation of IL-22-producing T cells. PLoS One. 2015; 10:e0130395.

118. Kawaura A, Takeda E, Tanida N, Nakagawa K, Yamamoto $\mathrm{H}$, Sawada K, Okano T. Inhibitory effect of long term 1 alpha-hydroxyvitamin D3 administration on Helicobacter pylori infection. J Clin Biochem Nutr. 2006; 38:103-06.

119. Lappe JM, Travers-Gustafson D, Davies KM, Recker RR, Heaney RP. Vitamin D and calcium supplementation reduces cancer risk: results of a randomized trial. Am J Clin Nutr. 2007; 85:1586-91.

120. Mark KA, Dumas KJ, Bhaumik D, Schilling B, Davis S, Oron TR, Sorensen DJ, Lucanic M, Brem RB, Melov S, Ramanathan A, Gibson BW, Lithgow GJ, Vitamin D. Vitamin D Promotes Protein Homeostasis and Longevity via the Stress Response Pathway Genes skn-1, ire-1, and xbp-1. Cell Reports. 2016; 17:1227-37. 